\title{
PENGARUH STATUS SOSIAL EKONOMI ORANG TUA DAN \\ PENDIDIKAN KEWIRAUSAHAAN TERHADAP MINAT BERWIRAUSAHA MAHASISWA DI UNIVERSITAS NEGERI MAKASSAR
}

\section{THE EFFECT OF PARENTS' SOCIO-ECONOMIC STATUS AND ENTREPRENEURSHIP EDUCATION TOWARD STUDENTS' ENTREPRENEURIAL INTERESTS AT UNIVERSITAS NEGERI MAKASSAR}

\author{
Andika Isma ${ }^{1}$, Sudarmiatin ${ }^{2}$, Muhammad Rakib ${ }^{3}$, Hajar Dewantara ${ }^{4}$ \\ 1,2 Program Studi Magister Manajemen, Fakultas Ekonomi dan Bisnis, ${ }^{3,4}$ Jurusan Bisnis dan \\ Kewirausahaan, Fakultas Ekonomi \\ ${ }^{1,2}$ Universitas Negeri Malang, ${ }^{3,4}$ Universitas Negeri Makasssar \\ Email: andikaisma.1904137@ students.um.ac.id ${ }^{1}$
}

\begin{abstract}
This study aims to determine the effect of parents' socio-economic status and entrepreneurship education on students' entrepreneurial interests at Universitas Negeri Makassar. This research is a quantitative study with a correlation approach. Data collection techniques were carried out by observation, interviews, documentation, and questionnaire distribution. The population in this study was 360 at students Universitas Negeri Makassar who participated and sent the Student Creativity Program (PKM) Entrepreneurship proposal in 2016-2018 and there were 72 students as the sample. The analysis technique used is multiple linear regression. The results of this study indicate that simultaneous parents' socio-economic status and entrepreneurship education significantly influence students' entrepreneurial interests. While partially, entrepreneurship education has an effect on students' entrepreneurial interests but for parents' socio-economic status shows no influence on students' entrepreneurial interests.
\end{abstract}

Keywords: parents' socio-economic status, entrepreneurship education, students' entrepreneurial interests

\begin{abstract}
Abstrak
Penelitian ini bertujuan untuk mengetahui pengaruh status sosial ekonomi orangtua dan pendidikan kewirausahan terhadap minat berwirausaha mahasiswa di Universitas Negeri Makassar. Penelitian ini merupakan penelitian kuantitatif dengan pendekatan korelasi. Teknik pengumpulan data dilakukan dengan observasi, wawancara, dokumentasi dan penyebaran angket (kuisioner). Populasi dalam penelitian ini sebanyak 360 mahasiswa Universitas Negeri Makassar yang menjadi peserta dan telah mengirimkan proposal Program Kreativitas Mahasiswa (PKM) Kewirausahaan pada tahun 2016-2018 dan sampel sebanyak 72 mahasiswa. Teknik analisis yang digunakan yaitu regresi linear berganda. Hasil penelitian ini menunjukkan bahwa secara simultan status sosial ekonomi orang tua dan pendidikan kewirausahaan berpengaruh signifikan terhadap minat berwirausaha mahasiswa. Sedangkan secara parsial, pendidikan kewirausahaan berpengaruh terhadap minat berwirausaha mahasiswa namun untuk status sosial ekonomi orang tua menunjukkan tidak adanya pengaruh terhadap minat berwirausaha mahasiswa.
\end{abstract}

Kata Kunci: status sosial ekonomi orangtua, pendidikan kewirausahan, minat berwirausaha 


\section{PENDAHULUAN}

Masalah pengangguran menjadi tantangan besar di Indonesia dan sampai saat ini masih sulit untuk diatasi ([1]; [2]; [3]). Hal ini disebabkan karena pertumbuhan penduduk yang terus meningkat, namun tidak disertai dengan bertambahnya lapangan pekerjaan ([4]; [5]; [6]).

Tingkat pengangguran terdidik yang berstatus sarjana dikhawatirkan akan terus meningkat [7] jika perguruan tinggi sebagai lembaga pencetak sarjana tidak memiliki kemampuan mengarahkan mahasiswa dan alumninya menciptakan lapangan kerja setelah lulus nanti ([8]; [9]). Selain itu, dengan rendahnya motivasi generasi muda Indonesia dalam berwirausaha saat ini menjadi masalah serius bagi berbagai pihak, baik pemerintah, dunia pendidikan, dunia industri, maupun masyarakat [10]. Fenomena ini semakin menambah beban pemerintah dalam mengurangi pengangguran.

Salah satu solusi yang ditempuh untuk mengatasi pengangguran di Indonesia adalah dengan menciptakan wirausaha ([11]; [8]; [9]; [12]). Dengan berwirausaha, dapat membantu pemerintah dalam menciptakan lapangan pekerjaan baru ([13]; [14]; [15]) dan juga mampu mengurangi jumlah pengangguran [16].

Menciptakan seorang wirausaha dapat dimulai melalui pendidikan kewirausahaan yang diajarkan di perguruan tinggi. Pendidikan kewirausahaan diharapkan mampu membangkitkan semangat berwirausaha ([17]; [18]; [19]). Pendidikan kewirausahaan juga diharapkan mampu memunculkan para wirausaha yang kreatif yang bisa menciptakan lapangan kerja dan bisa membantu mengurangi pengangguran yang tidak ada habisnya [20]. Pendidikan kewirausahaan tidak hanya memberikan landasan teoritis mengenai konsep kewirausahaan tetapi membentuk sikap, perilaku, dan pola pikir (mindset) seorang wirausaha ([21]; [22].

Kondisi status sosial ekonomi orang tua seseorang juga dipandang sebagai hal yang sangat penting dalam berwirausaha baik dari ukuran ilmu pengetahuan, ukuran kekayaan dan ukuran kehormatan mahasiswa berbedabeda, namun sebagian besar mahasiswa cendurung memiliki minat untuk berwirausaha. Faktor yang mempengaruhi status ekonomi seseorang yaitu; Pendidikan, Pekerjaan, keadaan ekonomi, latar belakang budaya, dan pendapatan [23].

Potensi perguruan tinggi yang seharusnya dapat menciptakan wirausaha-wirausaha baru dan fenomena mengubah pola pikir lulusan perguruan tinggi dari pencari kerja (job seeker) menjadi pencipta lapangan pekerjaan (job creator) [24] sebenarnya bukan permasalahan baru, namun telah menjadi masalah yang terus dicari dan dikembangkan solusinya. Pembinaan kewirausahaan mahasiswa diharapkan dapat menjadi solusi dan menghasilkan wirausaha muda berbasis keilmuan yang bertujuan untuk mengurangi angka pengangguran dengan solusinya yaitu berwirausaha.

Atas dasar pemikiran tersebut Direktorat Penelitian dan Pengabdian kepada Masyarakat (Ditlitabmas) Kementrian Riset dan Pendidikan Tinggi mengembangkan Program Kereativitas Program Kreativitas Mahasiswa (PKM) Kewirausahaan. PKM Kewirausahaan merupakan program pengembangan dan pemberian modal dasar mahasiswa dalam berwirausaha, berorientasi pada profit dan memasuki pasar [25].

Universitas Negeri Makassar sebagai salah satu perguruan tinggi negeri di Indonesia juga setiap tahunnya terlibat dalam Program Kreativitas Mahasiswa Kewirausahan, karena program ini merupakan salah satu cara meningkatkan minat mahasiswa dalam berwirausaha.

Jumlah mahasiswa Universitas Negeri Makassar yang menjadi peserta dan telah mengirimkan proposal Program Kreativitas Mahasiswa Kewirausahaan dalam 5 tahun terakhir dapat dilihat pada tabel 1 .

Tabel 1. Jumlah Mahasiswa Yang Telah Mengirim Proposal PKM Kewirausahaan Tahun 2015-2018 


\begin{tabular}{ccc}
\hline No & Tahun & $\begin{array}{c}\text { Jumlah Proposal } \\
\text { (Tim) }\end{array}$ \\
\hline 1 & 2014 & 45 \\
2 & 2015 & 45 \\
3 & 2016 & 122 \\
4 & 2017 & 183 \\
5 & 2018 & 55 \\
\hline & Total & $\mathbf{4 5 0}$ \\
\hline
\end{tabular}

Sumber: Staf Wakil Rektor Bidang Kemahasiswaan UNM, 2019.

Berdasarkan Tabel 1, jumlah mahasiswa Universitas Negeri Makassar yang telah mengirim proposal Program Kreativitas Mahasiswa Kewirausahaan dalam 5 tahun terakhir sebanyak 450 proposal. Dari data tersebut, terlihat bahwa jumlah pengusul yang telah mengirim proposal PKM Kewirausahaan sangat banyak dan berbeda setiap tahunnya tergantung kebijakan yang didapatkan oleh perguruan tinggi.

Hasil uraian diatas menunjukkan bahwa perlu adanya usaha untuk menumbuhkan minat berwirausaha mahasiswa Universitas Negeri Makassar mengingat semakin terbatasnya jumlah lapangan kerja yang ditawarkan di pasar tenaga kerja. Akan tetapi, minat berwirausaha tidak akan tumbuh dengan baik apabila tidak dilatih atau dipupuk sedari dini. Banyak faktor yang mempengaruhi minat berwirausaha salah satunya adalah status sosial ekonomi orang tua dan pendidikan kewirausahaan.

\section{METODE PENELITIAN}

Jenis penelitian yang digunakan dalam penelitian ini adalah penelitian korelasi. Pendekatan yang digunakan adalah pendekatan kuantitatif. Subjek dalam penelitian ini yaitu mahasiswa UNM yang telah mengirim proposal PKM Kewirausahaan hanya pada tahun 2016-2018. Populasi dalam penelitian ini yaitu mahasiswa Universitas Negeri Makassar yang telah mengirim proposal PKM Kewirausahaan pada tahun 2016-2018 sebanyak 360. Sedangkan sampel dalam penelitian ini tersebar di sembilan fakultas di Universitas Negeri Makassar. Teknik pengambilan sampel menggunakan teknik Probability Sampling atau lebih spesifiknya menggunakan teknik pengambilan Sampel Acak Sederhana (Simple Random Sampling). Teknik ini berlandaskan pada "Apabila populasi penelitian berjumlah lebih dari 100 maka sampel dapat diambil antara 10-15\% atau 20-25\% atau lebih" [26].

$$
\mathrm{n}=20 \% \times \mathrm{N}
$$

Dimana:

$$
\begin{aligned}
& \mathrm{n}=\text { Jumlah Sampel } \\
& \text { N=Jumlah Populasi }
\end{aligned}
$$

Populasi yang terdapat dalam penelitian ini berjumlah 360 mahasiswa, maka besarnya sampel pada penelitian ini, yaitu:

$$
\begin{aligned}
& \mathrm{n}=20 \% \times \mathrm{N} \\
& \mathrm{n}=20 \% \times 360 \\
& \mathrm{n}=72
\end{aligned}
$$

Jumlah keseluruhan responden dalam penelitian ini sebanyak 72 mahasiswa dan teknik yang digunakan dalam mengumpulkan data penelitian ini yaitu Observasi, Wawancara, Dokumentasi dan Kuisioner.

\section{HASIL PENELITIAN}

\section{Uji Asumsi Klasik}

1. Uji Normalitas

Pengujian normalitas data dengan menggunakan uji normalitas One-Sample Kolmogorov-Smirnov Test program computer SPSS for windows versi 21. Suatu data dikatakan berdistribusi normal pada taraf signifikan 5\% jika nilai Asymp. Sig lebih dari 0,05 . Hasil uji normalitas dapat dilihat pada tabel dibawah ini:

Tabel 2. Hasil Uji Normalitas Data One-Sample Kolmogrov-Smirnov Test

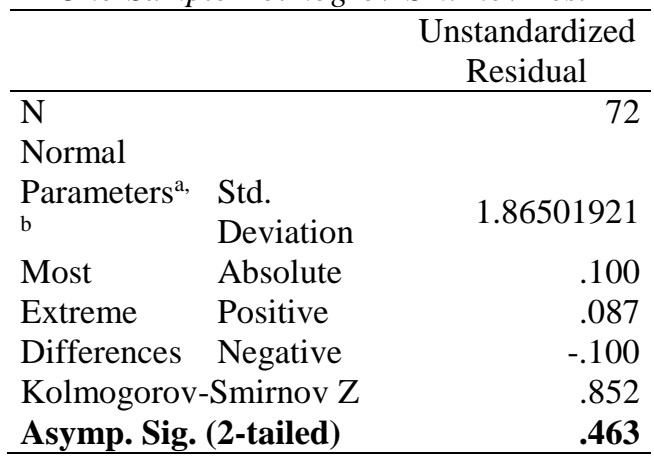

Berdasarkan tabel diatas, dapat dilihat bahwa nilai signifikan variabel secara keseluruhan adalah sebesar 0,463. Nilai Asymp. Sig variabel tersebut memiliki nilai 
diatas taraf signifikansi 0,05 maka distribusi data dari masing-masing variabel dikatakan normal.

\section{Uji Lineartitas}

Uji linearitas bertujuan untuk melihat apakah spesifikasi model yang digunakan sudah benar atau tidak. Suatu data dikatakan linear apabila nilai signifikan deviation from linearity lebih besar dari taraf signifikansi 0,05 . Hasil uji linearitas dapat dilihat pada tabel berikut:

Tabel 3. Hasil Uji Linearitas

\begin{tabular}{|c|c|c|c|c|}
\hline $\begin{array}{l}\mathbf{N} \\
\mathbf{0}\end{array}$ & Variabel & $\begin{array}{c}\text { Deviati } \\
\text { on } \\
\text { From } \\
\text { Lineari } \\
\text { ty }\end{array}$ & $\begin{array}{c}\text { Sig } \\
\text { nifi } \\
\text { kan } \\
\text { si }\end{array}$ & $\begin{array}{c}\text { Kete } \\
\text { rang } \\
\text { an }\end{array}$ \\
\hline 1 & $\begin{array}{l}\text { Minat } \\
\text { Berwirausa } \\
\text { ha terhadap } \\
\text { Status } \\
\text { Sosial } \\
\text { Ekonomi } \\
\text { Orangtua }\end{array}$ & 0,743 & $\begin{array}{c}0,0 \\
5\end{array}$ & $\begin{array}{l}\text { Line } \\
\text { ar }\end{array}$ \\
\hline 2 & $\begin{array}{l}\text { Minat } \\
\text { Berwirausa } \\
\text { ha terhadap } \\
\text { Pendidikan } \\
\text { Kewirausa } \\
\text { haan }\end{array}$ & 0,462 & $\begin{array}{c}0,0 \\
5\end{array}$ & $\begin{array}{l}\text { Line } \\
\text { ar }\end{array}$ \\
\hline
\end{tabular}

Berdasarkan tabel diatas, dapat dilihat bahwa nilai deviation from linearity variabel Minat Berwirausaha terhadap Sosial Ekonomi Orang Tua sebesar 0,743 sedangkan variabel Minat Berwirausaha terhadap Pendidikan Kewirausahaan sebesar 0,462 . Nilai deviation from linearity dari hubungan terhadap variabel yang ada memiliki nilai signifikansi diatas 0,05 maka data tersebut linear sehingga data bisa diolah lebih lanjut.

\section{Analisis Regresi Linear Berganda}

Pengujian menggunakan analisis regresi berganda bertujuan untuk mengetahui pengaruh variabel independen terhadap variabel dependen. Berdasarkan perhitungan dengan menggunakan SPSS 21 for windows dapat dilihat sebagai berikut:
Tabel 4. Hasil Analisis Regresi Linear Berganda

$$
\text { Coefficients }^{\mathbf{a}}
$$

\begin{tabular}{|c|c|c|c|c|c|}
\hline \multirow[t]{2}{*}{ Model } & \multicolumn{2}{|c|}{$\begin{array}{l}\text { Unstandard } \\
\text { ized } \\
\text { Coefficient } \\
\text { s } \\
\end{array}$} & \multirow{2}{*}{$\begin{array}{c}\begin{array}{c}\text { Standard } \\
\text { ized } \\
\text { Coefficie } \\
\text { nts }\end{array} \\
\text { Beta }\end{array}$} & \multirow[t]{2}{*}{$\mathrm{t}$} & \\
\hline & B & $\begin{array}{l}\text { Std. } \\
\text { Erro } \\
\text { r }\end{array}$ & & & \\
\hline (Const & 9.77 & 2.04 & & 4.7 & .0 \\
\hline ant) & 5 & 0 & & 91 & 00 \\
\hline $1 \mathrm{X} 1$ & .016 & .114 & .018 & $\begin{array}{r}.14 \\
0\end{array}$ & $\begin{array}{r}.8 \\
89\end{array}$ \\
\hline $\mathrm{X} 2$ & .414 & .102 & .524 & $\begin{array}{r}4.0 \\
45\end{array}$ & $\begin{array}{r}.0 \\
00\end{array}$ \\
\hline
\end{tabular}

a. Dependent Variable: Y

Berdasarkan Tabel 4, dapat diketahui persamaan regresi untuk penelitian ini adalah:

$$
\mathrm{Y}=9,775+0,016 \mathrm{X} 1+0,414 \mathrm{X} 2+\mathrm{e}
$$

Dimana:

Y : Minat Berwirausaha Mahasiswa

X1 : Status Sosial Ekonomi Orang Tua

X2 : Pendidikan Kewirausahaan

Persamaan regresi di atas menunjukkan nilai konstanta sebesar 9.775. Hal ini menjelaskan bahwa jika tidak ada kenaikan pada nilai variabel bebas, maka nilai minat berwirausaha mahasiswa (Y) adalah sebesar 9.775. Konstanta sebesar 9.775 tersebut juga menunjukkan Minat Berwirausaha jika Status Sosial Ekonomi Orang Tua dan Pendidikan Kewirausahaan sama dengan nol. Hal ini menunjukkan bahwa jika tidak ada Status Sosial Ekonomi Orang Tua dan Pendidikan Kewirausahaan maka Minat Berwirausaha sebesar 9.775. Sehingga dapat dikatakan apabila tidak terdapat variabel lain yang mendukung, Minat Berwirausaha akan tetap memiliki nilai sebesar 8,214.

Koefisien regresi untuk variabel Status Sosial Ekonomi Orang Tua sebesar 0,016, menunjukkan bahwa setiap penambahan (karena tanda +) Status Sosial Ekonomi Orang Tua sebesar 1\% maka akan menambah pengaruh minat berwirausaha mahasiswa sebesar 0,016. Koefisien Pendidikan Kewirausahaan sebesar 0,414, menunjukkan bahwa setiap penambahan (karena tanda + ) Pendidikan Kewirausahaan sebesar 1\% maka akan menambah pengaruh minat berwirausaha mahasiswa sebesar 0,414. 
Persamaan regresi tersebut menunjukkan bahwa variabel Status Sosial Ekonomi Orang Tua dan Pendidikan Kewirausahaan secara bersama-sama dapat memprediksi Minat Berwirausaha Mahasiswa Universitas Negeri Makassar yang mengikuti Program Kreativitas Mahasiswa (PKM).

\section{Uji Hipotesis}

\section{Uji Signifikan Secara Parsial}

Pengujian hipotesis secara parsial dimaksudkan untuk mengukur besarnya pengaruh Status Sosial Ekonomi Orang Tua (X1) dan Pendidikan Kewirausahaan (X2) secara parsial terhadap Minat Berwirausaha mahasiswa Universitas Negeri Makassar.

Tabel 5. Hasil Uji Signifikan Secara Parsial

\begin{tabular}{|c|c|c|c|c|c|}
\hline \multicolumn{6}{|c|}{ Coefficients $^{a}$} \\
\hline \multirow[t]{2}{*}{ Model } & $\begin{array}{r}\text { Unsta } \\
\text { izt } \\
\text { Coeff }\end{array}$ & $\begin{array}{l}\text { idard } \\
d \\
\text { cient }\end{array}$ & $\begin{array}{l}\text { Standard } \\
\text { ized } \\
\text { Coefficie } \\
\text { nts }\end{array}$ & $\mathrm{t}$ & $\begin{array}{l}\mathrm{Si} \\
\text { g. }\end{array}$ \\
\hline & B & $\begin{array}{l}\text { Std. } \\
\text { Erro } \\
\text { r }\end{array}$ & Beta & & \\
\hline (Const & 9.77 & 2.04 & & 4.7 & .0 \\
\hline ant) & 5 & 0 & & 91 & 00 \\
\hline $1 \mathrm{X} 1$ & .016 & .114 & .018 & $\begin{array}{r}.14 \\
0\end{array}$ & $\begin{array}{r}.8 \\
89\end{array}$ \\
\hline $\mathrm{X} 2$ & .414 & .102 & .524 & $\begin{array}{r}4.0 \\
45\end{array}$ & $\begin{array}{r}.0 \\
00\end{array}$ \\
\hline
\end{tabular}

a. Dependent Variable: Y

Adapun kriteria pengambilan keputusan adalah sebagai:

$\mathrm{H} 0$ diterima jika $\mathrm{t}_{\text {hitung }} \leq \mathrm{t}_{\text {tabel }}$ pada $\alpha=5 \%$

$\mathrm{H} 0$ ditolak jika $t_{\text {hitung }} \geq \mathrm{t}_{\text {tabel }}$ pada $\alpha=5 \%$

Dari hasil di atas dapat dianalisis hasil uji signifikan parsialnya sebagai berikut :

1. Variabel Status Sosial Ekonomi Orang

Tua (X1)

Berdasarkan hasil output perhitungan menggunakan program SPSS, diketahui bahwa untuk variabel Status Sosial Ekonomi Orang Tua (X1) nilai signifikansinya sebesar 0,889 . Karena nilai signifikansi lebih besar dari $\alpha=5 \%$ atau $0,889>0,05$ sehingga hipotesis nol (H0) diterima dan hipotesis alternative (Ha) ditolak. Artinya berdasarkan hasil tersebut dapat disimpulkan bahwa ada pengaruh namun tidak signifikan variable status sosial ekonomi orangtua terhadap minat berwirausaha mahasiswa.

Hal tersebut dikarenakan kedudukan atau posisi suatu keluarga dalam kelompok yang ditentukan oleh jenis aktivitas ekonomi, pendapatan, tingkat pendidikan, jenis tempat tinggal dan jabatan dalam organisasi khususnya pada orangtua mahasiswa bukanlah menjadi indikator yang berperan dalam peningkatan minat berwirausaha mahasiswa.

2. Variabel Pendidikan Kewirausahaan (X2)

Berdasarkan hasil perhitungan yang disajikan pada table output SPSS diperoleh signifikansi 0,000. Karena nilai signifikansi lebih kecil dari $5 \%$ atau $0,00<0,05$ sehingga hipotesis nol (H0) ditolak dan hipotesis alternative (Ha) diterima. Sehingga dapat disimpulkan bahwa Pendidikan Kewirausahaan (X2) berpengaruh secara signifikan terhadap minat berwirausaha mahasiswa. Dari persamaan regresi sebelumnya dapat diketahui Adanya pengaruh positif yang ditunjukkan oleh variabel pendidikan kewirausahaan yang mengindikasikan bahwa semakin tinggi pendidikan kewirausahaan yang dimiliki oleh mahasiswa maka semakin tinggi minat berwirausaha mahasiswa tersebut.

\section{Uji Signifikan Secara Simultan}

Pengujian hipotesis secara simultan dimaksudkan untuk mengukur besarnya pengaruh Status Sosial Ekonomi Orang Tua (X1) dan Pendidikan Kewirausahaan (X2) secara bersama-sama terhadap variabel terikatnya minat berwirausaha mahasiswa Universitas Negeri Makassar.

Tabel 6. Hasil Uji Signifikan Simultan (Uji F)

\begin{tabular}{|c|c|c|c|c|}
\hline \multicolumn{5}{|c|}{ ANOVA $^{a}$} \\
\hline Model & $\begin{array}{l}\text { Sum } \\
\text { of } \\
\text { Squar } \\
\text { es }\end{array}$ & $\begin{array}{cc}\text { D } & \text { Mean } \\
\mathrm{f} & \text { Squa } \\
& \text { re }\end{array}$ & $\mathrm{F}$ & Sig. \\
\hline Regressi & 99.48 & 49.74 & 13.89 & .00 \\
\hline on & 5 & 3 & 8 & $0^{\mathrm{b}}$ \\
\hline 1 Residual & $\begin{array}{r}246.9 \\
59\end{array}$ & $\begin{array}{ll}6 & 3.579 \\
9 & \end{array}$ & & \\
\hline Total & $\begin{array}{r}346.4 \\
44\end{array}$ & $\begin{array}{l}7 \\
1\end{array}$ & & \\
\hline
\end{tabular}

a. Dependent Variable: Y

b. Predictors: (Constant), X2, X1

Berdasarkan tabel di atas, diperoleh nilai signifikansi sebesar 0,000 . Nilai signifikansi ini lebih kecil dari nilai $\alpha$ yaitu 5\%. Dari hasil 
tersebut diketahui nilai signifikansi 0,000 lebih kecil dari nilai $\alpha=0,05$ atau $0,00<0,05$. Hal ini menunjukkan bahwa H0 ditolak dan Ha diterima. Jadi, dapat disimpulkan bahwa Status Sosial Ekonomi Orang Tua dan Pendidikan Kewirausahaan secara simultan berpengaruh signifikan terhadap minat berwirausaha mahasiswa.

\section{Uji Koefisien Determinasi}

Jika determinasi $\left(\mathrm{R}^{2}\right)$ semakin besar (mendekati satu), maka dapat dikatakan bahwa pengaruh variabel independen adalah besar terhadap variabel dependen.

Tabel 7. Uji Koefisien Determinasi (R2)

\begin{tabular}{|c|c|c|c|c|}
\hline \multicolumn{5}{|c|}{ Model Summary } \\
\hline Model & $\mathrm{R}$ & $\begin{array}{c}\mathrm{R} \\
\text { Square }\end{array}$ & $\begin{array}{c}\text { Adjusted } \\
\text { R } \\
\text { Square }\end{array}$ & $\begin{array}{l}\text { Std. Error } \\
\text { of the } \\
\text { Estimate }\end{array}$ \\
\hline 1 & $.536^{\mathrm{a}}$ & .287 & .266 & 1.89186 \\
\hline
\end{tabular}

a. Predictors: (Constant), X2, X1

b. Dependent Variable: Y

Berdasarkan Tabel 7, diketahui R Square sebesar 0,287 dikalikan 100 persen sehingga dapat diketahui besarnya sumbangan (kontribusi) variabel X1 (Status Sosial Ekonomi Orang Tua) dan X2 (Pendidikan Kewirausahaan) terhadap variabel Y (Minat Berwirausaha) adalah 28,7 persen dan sebesar 71,3 dipengaruhi oleh faktor lain yang tidak diteliti dalam penelitian ini.

\section{PEMBAHASAN}

\section{Pengaruh Status Sosial Ekonomi Orang}

\section{Tua Terhadap Minat Berwirausaha}

Hasil uji hipotesis menunjukkan bahwa terjadi penolakan terhadap hipotesis yang diajukan. Dengan merujuk pada hasil olah data, hasil yang diperoleh yakni secara parsial variabel status sosial ekonomi orang tua tidak berpengaruh secara signifikan terhadap minat berwirausaha mahasiswa. Jika dilihat pada analisis regresi berganda sumbangan nilai peningkatan minat berwirausaha setiap peningkatan nilai variabel status sosial ekonomi orang tua juga cenderung rendah. Selain itu berdasarkan pengamatan langsung dari peneliti dilapangan diperoleh analisa bahwa memang status sosial ekonomi orang tua tidak terlalu mempengaruhi minat mahasiswa berwirausaha, apapun latar belakang dari orangtua mahasiswa bukanlah menjadi faktor penentu hadirnya minat mahasiswa dalam berwirausaha.

Hasil penelitian ini juga mendukung beberapa hasil penelitian yang telah dilakukan sebelumnya, seperti penelitian yang dilakukan oleh Ref. [27] bahwa dari segi pengaruh tidak terdapat pengaruh yang signifikan antara variabel bebas (status sosial ekonomi orang tua) terhadap variabel terikat (minat berwirausaha).

Selain itu, hasil penelitian ini juga sejalan dengan penelitian yang dilakukan oleh Ref. [28] bahwa secara simultan pendidikan terakhir orang tua dan penghasilan orang tua tidak memiliki pengaruh terhadap minat berwirausaha. Hal tersebut berarti bahwa status sosial ekonomi orangtua baik dilihat dari latar belakang pendidikan ataupun penghasilan tetap tidak memiliki pengaruh yang signifikan terhadap peningkatan minat berwirausaha mahasiswa, biasanya minat lahir dari mahasiswa itu sendiri apapun latar belakang status sosial orangtuanya.

\section{Pengaruh Pendidikan Kewirausahaan Terhadap Minat Berwirausaha}

Hasil uji hipotesis menunjukkan bahwa secara parsial variabel Pendidikan Kewirausahaan berpengaruh secara signifikan terhadap minat berwirausaha mahasiswa. Hal tersebut sejalan dengan analisis regresi berganda yang menunjukkan terjadinya peningkatan minat berwirausaha setiap terjadi penambahan pada variabel pendidikan kewirausahaan. Sebagaimana yang peneliti dapati di lapangan bahwa kebanyakan mahasiswa semakin memiliki minat untuk berwirausaha setelah mendapatkan mata kuliah pendidikan kewirausahaan, hal tersebut bisa jadi sebagai stimulus bagi mahasiswa untuk dapat memulai mendirikan usaha. Tidak sedikit pula yang telah memulai mendirikan usaha setelah mendapatkan proses pendidikan kewirausahaan jadi melalui pendidikan kewirausahaan yang diperoleh di kampus 
bukan hanya sebatas meningkatkan minat berwirausaha namun sebagai pendorong untu memulai merintis usaha.

Hasil penelitian ini konsisten dengan hasil penelitian sebelumnya [29],[30],[22] bahwa pendidikan kewirausahaan berpengaruh terhadap minat berwirausaha. Selain itu, Ref. [31], [32], menyatakan bahwa salah satu faktor pendorong pertumbuhan kewirausahaan di suatu negara terletak pada peranan universitas melalui penyelenggaraan pendidikan kewirausahaan. Pendidikan kewirausahaan sebagai salah satu langkah praktis dalam rangka menciptakan mahasiswa yang berjiwa wirausaha dan pada prinsipnya akan memicu keinginan mahasiswa untuk berwirausaha. Hal ini dapat terjadi karena dalam pendidikan kewirausahaan mahasiswa akan diberikan tips atau kiat dalam menggali dan mengaktualkan potensi serta kemampuan wirausahanya.

\section{Minat Berwirausaha Mahasiswa Universitas Negeri Makassar}

Hasil uji hipotesis menunjukkan bahwa minat berwirausaha mahasiswa Universitas Negeri Makassar berada dalam kategori sedang. Hasil penelitian ini sesuai dengan penelitian sebelumnya Ref. [32],[33],[34], bahwa minat berwirausaha merupakan pilihan seseorang karena merasa tertarik, senang dan berkeinginan untuk berwirausaha serta berani mengambil resiko untuk meraih kesuksesan. Wirausaha akan muncul ketika seseorang berani mengembangkan ide-ide atau usaha-usaha yang dimiliki melalui berbagai sarana atau cara yang dilakukan. Menjadikan seseorang menjadi berani mengembangkan ide dan usahanya dapat melalui minat berwirausaha yang kuat. Dua hal tersebut harus saling berhubungan agar tercipta wirausaha yang kuat dan tangguh serta berkualitas.

Hasil penelitian ini juga sesuai dengan Ref. [35] yang menyatakan bahwa minat berwirausaha dipengaruhi oleh beberapa faktor diantaranya, yaitu: 1) faktor personal, yang menyangkut aspek kepribadian termasuk seseorang. 2) faktor environtment, yang menyangkut lingkungan termasuk pendidikan kewirausahaan. 3) faktor sosiological, yang menyangkut hubungan dengan keluarga termasuk status sosial ekonomi orang tua.

Mahasiswa memiliki semangat yang tinggi setiap tahunnya menjelang dibukanya Program Kreativitas Mahasiswa Kewirausahaan (PKM-K). Program ini merupakan salah satu kegiatan rutin yang dilaksanakan setiap tahunnya oleh Direktorat Jenderal Pembelajaran dan Kemahasiswaan Kementerian Pendidikan dan Kebudayaan (Kemendikbud), sehingga Universitas Negeri Makassar dengan salah satu visinya dalam mengembangkan jiwa kewirausahaan generasi muda khususnya mahasiswa Universitas Negeri Makassar, tentunya menjadikan Program Kreativitas Mahasiswa Kewirausahaan (PKM-K) ini sebagai ajang dalam menunmbuh kembangkan jiwa wirausaha mahasiswa.

\section{Pengaruh Status Sosial Ekonomi Orang Tua Dan Pendidikan Kewirausahaan Terhadap Minat Berwirausaha}

Dari hasil olah data yang dilakukan, maka diperoleh hasil yang menunjukkan bahwa status sosial ekonomi orang tua pendidikan kewirausahaan secara simultan berpengaruh signifikan terhadap minat berwirausaha mahasiswa. Walaupun secara parsial kedua variabel bebas menunjukkan pengaruh yang berbeda namun secara simultan hasilnya menunjukkan bahwa kedua variabel bebas memiliki pengaruh yang siginifikan terhadap variabel terikat dalam hal ini minat berwirausaha. Adapun jika melihat kontribusi pengaruh dari setiap variabel maka yang lebih dominan mempengaruhi minat berwirausaha adalah dari pendidikan kewirausahaan.

Pendidikan kewirausahaan merupakan pengetahuan atau pemahaman dasar tentang kewirausahaan yang dapat dijadikan sebagai bekal penting bagi seseorang untuk memulai suatu usaha [36]. Dalam hal ini pendidikan kewirausahaan tidak hanya yang diperoleh 
mahasiswa saat perkuliahan saja, melainkan pengetahuan dari keluarga dan lingkungan serta pelatihan-pelatihan kewirausahaaan yang dapat dijadikan sebagai modal untuk memilih karir sebagai wirausahawan [37].

Minat berwirausaha juga dapat muncul karena adanya pengetahuan tentang wirausaha dan dilanjutkan dengan ikut berpartisipasi dalam memperoleh pengalamann kewirausahaan yang pada akhirnya menimbulkan minat untuk berwirausaha [27]. Minat berwirausaha mahasiswa yang ditemukan peneliti lebih kepada inisiatif mereka sendiri tanpa dipengaruhi secara dominan oleh latar belakang orang tua atau status sosial ekonomi orang tua mereka.

Hasil penelitian ini juga sejalan dengan hasil penelitian yang dilakukan oleh Ref. [22], ditemukan bahwa pendidikan kewirausahaan berpengaruh secara signifikan terhadap minat berwirausaha dan minat wirausaha mahasiswa juga diperkuat oleh pekerjaan orang tua. Kemudian diperkuat oleh penelitian Ref. [38] yang menunjukkan bahwa pembelajaran mata kuliah kewirausahaan dilihat dari faktor intrinsik dan faktor ekstrinsik, ternyata secara keseluruhan mampu mempengaruhi minat mahasiswa menjadi wirausahawan. Selain itu, dalam penelitian lain yang dilakukan oleh Ref. [39] menunjukkan bahwa lingkungan tempat tinggal, intensitas pendidikan ekonomi keluarga, dan pembelajaran kewirausahaan berpengaruh positif dan signifikan terhadap minat berwirausaha mahasiswa.

\section{KESIMPULAN}

Berdasarkan hasil penelitian dan analisis data yang telah dilakukan, dapat ditarik kesimpulan bahwa secara parsial tidak terdapat pengaruh antara status ekonomi orang tua terhadap minat berwirausaha mahasiswa Universitas Negeri Makassar. Secara parsial terdapat pengaruh yang antara Pendidikan Kewirausahaan terhadap minat berwirausaha mahasiswa Universitas Negeri Makassar. Secara simultan status sosial ekonomi orang tua dan pendidikan kewirausahaan berpengaruh signifikan terhadap minat berwirausaha mahasiswa Universitas Negeri Makassar.

\section{DAFTAR PUSTAKA}

[1]. Soleh, A., 2017. Masalah Ketenagakerjaan Dan Pengangguran Di Indonesia. Jurnal Ilmiah Cano Ekonomos, 6(2), pp.83-92.

[2]. Maryati, S., 2015. Dinamika pengangguran terdidik: tantangan menuju bonus demografi di Indonesia. Economica: Jurnal Program Studi Pendidikan Ekonomi STKIP PGRI Sumatera Barat, 3(2), pp.124-136.

[3]. Tantri, E. and Ratnasari, V., 2016. Pengaruh Indikator Kependudukan Terhadap Tingkat Pengangguran Terbuka di Indonesia dengan Pendekatan Regresi Panel. Jurnal Sains dan Seni ITS, 5(2).

[4]. Widarjono, A., 1999. Penduduk dan pertumbuhan ekonomi di Indonesia: Analisis kausalitas. Economic Journal of Emerging Markets, 4(2), pp.147169.

[5]. Purwasih, H., 2017. Pengaruh Pertumbuhan Sektor Industri Terhadap Penyerapan Tenaga Kerja di Kabupaten Sidoarjo. Jurnal Pendidikan Ekonomi (JUPE), 5(1).

[6]. Yuliarmi, N.N. and Senet, D.R., 2014. Faktor-Faktor yang Mempengaruhi Jumlah Pengangguran di Provinsi Bali. E-Jurnal Ekonomi Pembangunan Universitas Udayana, 3(6), p.44460.

[7]. Warnadi, W., Triyono, A., Armita, R.V. \& Adrianti, C., 2019. Pengaruh Pendidikan Kewirausahaan Terhadap Motivasi Berwirausaha dan Keterampilan Berwirausaha (Studi Kasus Pada Mahasiswa Sekolah Tinggi Ilmu Ekonomi Indragiri (STIE-I RENGAT). Jurnal Ilmiah Mahasiswa Manajemen dan Bisnis (JIM2B), 2(1), pp.86-100. 
[8]. Budy, D.A., 2017. Pengaruh Pendidikan Kewirausahaan dan Motivasi Kewirausahaan Terhadap Keterampilan Berwirausaha Mahasiswa Universitas 17 Agustus 1945 Jakarta. Journal for Business and Entrepreneurship, 1(1).

[9]. Lubis, P.K.D., 2018. Pengaruh Pendidikan Kewirausahaan dan Keterampilan Berwirausaha Terhadap Motivasi Berwirausaha Mahasiswa Pendidikan Ekonomi Universitas Negeri Medan. NIAGAWAN, 7(2), pp.95-101.

[10]. Nugrahaningsih, H., 2016. Pengaruh Pengetahuan dan Motivasi terhadap Keinginan Berwirausaha pada Mahasiswa Manajemen di Jakarta Utara. Journal of Business Studies, 1(2).

[11]. Nalling, Z. and Jannah, R., 2018. Pengaruh Efektifitas Pembelajaran Mata Kuliah Kewirausahaan terhadap Minat Berwirausaha Mahasiswa Program Studi Perbankan Syariah IAIN Bone. Journal of Economic, Public, and Accounting (JEPA), 1(1), pp.51-57.

[12]. Athia, I., Saraswati, E. and Normaladewi, A., 2018. Penerapan Business Model Canvas (BMC) Untuk Mendorong Mindset Kewirausahaan Di Kalangan Mahasiswa Universitas Islam Malang. JU-ke (Jurnal Ketahanan Pangan), 2(1), pp.66-75.

[13]. Munfaqiroh, S., 2016. Faktor yang mempengaruhi wirausaha wanita miskin untuk mencapai keberhasilan usaha. Jurnal Jibeka, 10(1), pp.57-65.

[14]. Savitri, C., 2017. Upaya Menumbuhkan Minat Berwirausaha Pada Mahasiswa Prodi Manajemen Di UBP Karawang. Jurnal Manajemen \& Bisnis Kreatif, 3(1).

[15]. Winarto, W. and Purba, J.H., 2019. Analisis Faktor-Faktor Yang Berpengaruh Pada Niat Berwirausaha (Studi Kasus Pada Mahasiswa Fakultas Ekonomi di Kota
Medan. Jurnal Ilmu Manajemen METHONOMIX, 2(2), pp.85-94.

[16]. Franita, R., 2016. Analisa Pengangguran di Indonesia. Jurnal Ilmu Pengetahuan Sosial, 1, pp.8893.

[17]. Kasih, Y., 2013. Mewujudkan pendidikan kewirausahaan di perguruan tinggi melalui proses pembelajaran yang berkelanjutan. In Forum Bisnis dan Kewirausahaan Jurnal Ilmiah STIE MDP (Vol. 2, No. 2, pp. 164-182). STIE MDP.

[18]. Asmani, Jamal Ma'mur. 2011. Tips Pintar PTK, Penelitian Tindakan Kelas. Jakarta: Transmedi.

[19]. Widowati, S.S. and Wahyuningsih, U., 2015. Pendidikan Kewirausahaan Dalam Pelaksanaan On Job Traning Siswa SMK Negeri 6 Semarang. Penelitian-pendidikan, 441.

[20]. Nareshwari, C.P. and Nareshwari, P.H., 2016. Kontribusi Prestasi Belajar dan Minat Kewirausahaan terhadap Kemampuan Berwirausaha Siswa Kelas XI SMK Negeri 2 Pengasih Kulon Progo. E-Journal Pend. Teknik Sipil Dan Perencanaan, 4(2), p.55.

[21]. Ranto, D.W.P., 2016. Membangun perilaku entrepreneur pada mahasiswa melalui entrepreneurship education. Jurnal Bisnis, Manajemen, dan Akuntansi, 3(1).

[22]. Lestari, R.B. and Wijaya, T., 2012. Pengaruh Pendidikan Kewirausahaan Terhadap Minat Berwirausaha Mahasiswa di STIE MDP, STMIK MDP, dan STIE MUSI. Forum Bisnis Dan Kewirausahaan Jurnal Ilmiah STIE MDP (Vol. 1, No. 2, pp. 112119). STIE MDP.

[23]. Friedman. 2004. Keperawatan Keluarga. Jakarta: EGC.

[24]. Prayitno, Y.H., 2013. Pengaruh Minat Mahasiswa Jurusan Akuntansi terhadap Pilihan Pekerjaan. Jurnal 
ilmiah Akuntansi dan

Humanika, 3(1).

[25]. Direktorat Jenderal Pembelajaran dan Kemahasiswaan - Kementerian Pendidikan dan Kebudayaan. 2019. Pedoman PKM 2020. Available at: https://simbelmawa.kemdikbud.go.id/ portal/. Diunduh pada 26 Juni 2020.

[26]. Arikunto, S. 2013. Prosedur Penelitian Suatu Pendekatan Praktik. Jakarta: PT. Rineka Cipta.

[27]. Wulandari, Retno. 2013. Pengaruh Status Sosial Ekonomi Orangtua Terhadap Minat Berwirausaha Mahasiswa Program Studi Pendidikan Ekonomi. Available at: http://jurnal.untan.ac.id. Diunduh pada 25 Juni 2020.

[28]. Umam, K. and Nurhasan Syah, M.P., 2019. Pengaruh Status Sosial Ekonomi Orang Tua Terhadap Minat Berwirausaha Mahasiswa Teknik Sipil. CIVED (Journal of Civil Engineering and Vocational Education), 6(1).

[29]. Setiawan, D. and Sukanti, S., 2016. Pengaruh Ekspektasi Pendapatan, Lingkungan Keluarga dan Pendidikan Kewirausahaan Terhadap Minat Berwirausaha. Jurnal Profita: Kajian Ilmu Akuntansi, 4(7).

[30]. Syaifudin, A. and Sagoro, E.M., 2017. Pengaruh Kepribadian, Lingkungan Keluarga Dan Pendidikan Kewirausahaan Terhadap Minat Berwirausaha Mahasiswa Akuntansi. Jurnal Profita: Kajian Ilmu Akuntansi, 5(8).

[31]. Zimmerer, T.W., Scarborough, N.M. and Wilson, D., 2008. Kewirausahaan dan Manajemen Usaha Kecil. Jakarta: Salemba Empat, 85.

[32]. Aras, M., Musa, C.I. and Rakib, M., 2020. Faktor Determinan yang Memengaruhi Minat Berwirausaha Mahasiswa. Phinisi Integration Review, 3(1), pp.55-66.
[33]. Rosmiati, R., Junias, D.T.S. and Munawar, M., 2015. Sikap, motivasi, dan minat berwirausaha mahasiswa. Jurnal Manajemen dan Kewirausahaan, 17(1), pp.21-30.

[34]. Budiati, Y., Yani, T.E. and Universari, N., 2012. Minat Mahasiswa Menjadi Wirausaha (Studi Pada Mahasiswa Fakultas Ekonomi Universitas Semarang). Jurnal Dinamika Sosbud, 14(1), pp.89-100.

[35]. Alma, B., 2013. Kewirausahaan. Bandung: Alfabeta.

[36]. Rakib, M., 2016. Entrepreneurship Education Development In Dealing Asean Economic Community. In Proceeding International Conference on Mathematic, Science, Technology, Education and their Applications (Vol. 1, No. 1).

[37]. Atmaja, A.T. and Margunani, M., 2016. Pengaruh Pendidikan Kewirausahaan dan Aktivitas Wirausaha terhadap Minat Berwirausaha Mahasiswa Universitas Negeri Semarang. Economic Education Analysis Journal, 5(3), pp.774-774.

[38]. Hermina, dkk. 2011. Pengaruh Mata Kuliah Kewirausahaan Terhadap Minat Mahasiswa Menjadi Wirausaha Pada Program Studi Administrasi Bisnis Politeknik Negeri Pontianak. Dalam Jurnal Eksos, Volume 7 No. 2. Hal 130-141. Pontianak: Politeknik Negeri Pontianak.

[39]. Muchtar, Y., Azis, M. and Rakib, M., 2019. Pengaruh Lingkungan Tempat Tinggal, Intensitas Pendidikan Ekonomi Keluarga, dan Pembelajaran Kewirausahaan Terhadap Minat Berwirausaha Mahasiswa (Studi Di Fakultas Ekonomi Universitas Negeri Makassar). Economix, 6(2). 